\title{
SURVEY OF RECENT DEVELOPMENTS IN INDIANA PRODUCT LIABILITY LAW
}

\author{
JOSEPH R. ALBERTS* \\ ROBERT B. THORNBURG** \\ HILARY G. BUTTRICK ${ }^{* * *}$
}

\section{INTRODUCTION}

This Survey reviews the significant product liability cases decided during the survey period. ${ }^{1}$ It offers select commentary and context, and organizes its treatment of the relevant cases into a basic structure that mirrors the Indiana Product Liability Act ("IPLA"). ${ }^{2}$ This Survey does not attempt to address all product liability cases decided during the survey period in detail. Rather, it focuses on cases involving important substantive product liability concepts arising under Indiana law and offers appropriate background information about the IPLA. ${ }^{3}$

As has been true in some recent years, the 2015 cases fell within the traditionally popular areas for substantive treatment, such as warning and design defects, the use of expert witnesses in product liability cases, and federal preemption.

\section{THE SCOPE OF THE IPLA}

The IPLA regulates actions against manufacturers or sellers by users or consumers. ${ }^{4}$ The IPLA regulates these actions when a product causes physical harm, "regardless of the substantive legal theory or theories upon which the action is brought." Read together, Indiana Code sections 34-20-1-1 and 34-20-2-

* Senior Counsel, The Dow Chemical Company, Midland, Michigan and Dow AgroSciences LLC, Indianapolis, Indiana. B.A., cum laude, 1991, Hanover College; J.D., magna cum laude, 1994, Indiana University Robert H. McKinney School of Law. The authors thank Dean Barnhard and Adey Adenrele for their research and editing assistance.

** Member, Frost Brown Todd LLC, Indianapolis. B.S., cum laude, Ball State University; J.D., 1996, Indiana University Maurer School of Law.

*** Assistant Professor of Business Law, Butler University College of Business, Indianapolis. B.A., summa cum laude, 1999, DePauw University; J.D., summa cum laude, 2002, Indiana University Robert H. McKinney School of Law.

1. The survey period is October 1, 2014 to September 30, 2015.

2. IND. CODE $\S \S 34-20-1-1$ to -9-1 (2016). This Survey follows the lead of the Indiana General Assembly and employs the term "product liability" (not "products liability") when referring to actions governed by the IPLA.

3. For example, an interesting product liability class action alleging design, manufacturing, and warning defect theories against football helmet manufacturers is pending in federal court in Indiana, but it involves the application of Washington law, and, therefore, will not be addressed in detail in this Survey. See DuRocher v. Riddell, Inc., 97 F. Supp. 3d. 1006 (S.D. Ind. 2015).

4. IND. CODE $\S 34-20-1-1$.

5. Id. $\S 34-6-2-115$. 
1 establish five unmistakable threshold requirements for IPLA liability: (1) a claimant who is a user or consumer and is also "in the class of persons that the seller should reasonably foresee as being subject to the harm caused by the defective condition"; (2) a defendant that is a manufacturer or a "seller . . . engaged in the business of selling [a] product"; (3) "physical harm caused by a product"; 8 (4) a "product in a defective condition unreasonably dangerous to [a] user or consumer" or to his or her property;" and (5) a product that "reach[ed] the user or consumer without substantial alteration in [its] condition." "In diana Code section 34-20-1-1 clearly establishes the IPLA regulates every claim which satisfies the five threshold requirements, "regardless of the substantive legal theory or theories upon which the action is brought." 11

\section{A. User/Consumer and Manufacturer/Seller}

Over the last decade or so, there have been a number of cases addressing the scope and reach of the IPLA. Several of those cases addressed who may file suit in Indiana as product liability plaintiffs because they are "users"12 or "consumers." By the same token, there is a fairly robust body of case law identifying people and entities that are "manufacturers"14 or "sellers" 15 and,

6. Id. $\S 34-20-2-1(1)$.

7. Id. $\S 34-20-2-1(2)$. For example, corner lemonade stand operators and garage sale sponsors are excluded from IPLA liability, according to the latter section.

8. Id. $\S 34-20-1-1$.

9. Id. $\S 34-20-2-1$.

10. Id. $\S 34-20-2-1(3)$.

11. Id. $\S 34-20-1-1$.

12. Id. § 34-6-2-147.

13. Id. § 34-20-1-1. A literal interpretation of the IPLA demonstrates even if a claimant qualifies as a statutorily-defined "user" or "consumer," before proceeding with a claim under the IPLA, he or she also must satisfy another statutorily-defined threshold. Id. § 34-20-2-1(1). That additional threshold is found in Indiana Code section 34-20-2-1(1), which requires the "user" or "consumer" also be "in the class of persons that the seller should reasonably foresee as being subject to the harm caused by the defective condition." Id. Thus, the plain language of the statute assumes a person or entity must already qualify as a "user" or a "consumer" before a separate "reasonable foreseeability" analysis is undertaken. In that regard, it does not appear the IPLA provides a remedy to a claimant whom a seller might reasonably foresee as being subject to the harm caused by a product's defective condition if that claimant does not fall within the IPLA's definition of "user" or "consumer." Two of the leading recent cases addressing "users" and “consumers" include Vaughn v. Daniels Co., 841 N.E.2d 1133 (Ind. 2006), and Butler v. City of Peru, 733 N.E.2d 912 (Ind. 2000).

14. IND. CODE $§ 34-6-2-77$. For purposes of the IPLA, a manufacturer is "a person or an entity who designs, assembles, fabricates, produces, constructs, or otherwise prepares a product or a component part of a product before the sale of the product to a user or consumer." Id. § 34-6-277(a). A few of the more recent influential cases that evaluated whether an entity qualifies as a "manufacturer" under the IPLA include Mesman v. Crane Pro Services, 512 F.3d 352 (7th Cir. 2008), Pentony v. Valparaiso Department of Parks \& Recreation, 866 F. Supp. 2d 1002 (N.D. Ind. 
therefore, proper defendants in Indiana product liability cases.

The 2015 survey period added two more decisions to the growing body of case law in this area. In the first case, Shelter Insurance Cos. v. Big Lots Stores, Inc., ${ }^{16}$ a Kenmore coffee maker purchased at a Big Lots retail store allegedly caused a large fire loss. ${ }^{17}$ After paying the claim, the homeowner's insurer filed suit against Big Lots, Sears, Roebuck and Company, and Spectrum Brands claiming, among other things, the coffee maker possessed a manufacturing defect. ${ }^{18}$ Quoting from the IPLA, the court noted the circumstances under which a seller could be strictly liable for manufacturing defects were very limited. ${ }^{19}$ To be subject to strict liability, a seller must either (1) be the manufacturer of the product, or, (2) the court must be unable to acquire jurisdiction over the manufacturer and the seller must be the manufacturer's principal distributor or seller over whom the court may hold jurisdiction. ${ }^{20}$

Shelter Insurance Company's amended complaint alleged Spectrum Brands was the manufacturer and Sears, Roebuck and Company was both a manufacturer and seller under the IPLA. ${ }^{21}$ Both of these defendants settled with the plaintiff and were dismissed. ${ }^{22}$ The insurer did not claim Big Lots was the manufacturer. ${ }^{23}$ Thus, Big Lots could only be liable for a manufacturing defect claim if it was the principal distributor or seller of the coffee maker alleged to have caused the fire. ${ }^{24}$ The court noted the evidence in the record was insufficient; it merely established

2012), and Warriner v. DC Marshall Jeep, 962 N.E.2d 1263 (Ind. Ct. App. 2012).

15. IND. CODE $§ 34-6-2-136$. The IPLA defines a seller as "a person engaged in the business of selling or leasing a product for resale, use, or consumption." Id. Indiana Code section 34-20-2-1 adds three additional and clarifying requirements as it relates to "sellers." First, an IPLA defendant must have sold, leased, or otherwise placed an allegedly defective product in the stream of commerce. $I d$. Second, the seller must be in the business of selling the product. $I d$. And, third, the seller expects the product to reach and, in fact, did reach the user or consumer without substantial alteration. Id.; see also Williams v. REP Corp., 302 F.3d 660, 662-64 (7th Cir. 2002). Sellers can also be held liable as manufacturers in two ways. First, a seller may be held liable as a manufacturer if the seller fits within the definition of "manufacturer" found in Indiana Code section 34-6-2-77(a). Second, a seller may be held liable as a manufacturer "[i]f a court is unable to hold jurisdiction over a particular manufacturer" and if the seller is the "manufacturer's principal distributor or seller." Kennedy v. Guess, Inc., 806 N.E.2d 776, 781 (Ind. 2004) (quoting IND. CoDE § 34-20-2-4 (1999)). When the theory of liability is based upon "strict liability in tort," Indiana Code section 34-20-2-3 makes clear a "seller" that cannot otherwise be deemed a "manufacturer" is not liable and is not a proper IPLA defendant.

16. No. 3:12-CV-433 JVB, 2014 WL 4494382 (N.D. Ind. Sept. 10, 2014).

17. Id. at $* 1$.

18. Id.

19. Id. at $* 1-2$.

20. Id.

21. $I d$. at *1.

22. Id.

23. $I d$. at $* 2$.

24. Id. 
Big Lots sold the coffee maker. ${ }^{25}$ Hence, no reasonable jury could conclude Big Lots was the manufacturer's principal distributor or seller and the plaintiff's strict liability claims failed. ${ }^{26}$

In the second case, Heritage Operating LP v. Mauck, ${ }^{27}$ the court determined Empire Gas, a retail distributor of propane, was not strictly liable to two plaintiffs injured in a propane gas explosion because it was a seller and not a manufacturer under the IPLA. ${ }^{28}$ A prior tenant at a leased property contacted Empire Gas to have a propane tank filled outside a mobile home he was renting. ${ }^{29}$ After the prior tenant died, Empire Gas was contacted..$^{30}$ A refund for the unused portion of propane remaining in the tank was issued, a lock was placed on the valve which allowed propane to flow from the tank, and a red tag was placed on the locked valve warning of the "danger[s] of propane and prohibit[ing] unauthorized individuals from tampering with or removing the lock. ${ }^{31}$

A few months later, new tenants moved into the mobile home. ${ }^{32}$ The landlord showed the new tenants the propane tank and indicated Empire Gas had installed a lock on the tank and would have to be contacted to have the propane service restored to the property. ${ }^{33}$ But the new tenants never contacted Empire Gas to have the propane service restored and the lock removed. ${ }^{34}$ When the weather became colder, one of the new tenants went to the propane tank and discovered the lock had mysteriously been removed, the gas line had been connected, and the valve had been turned on. ${ }^{35}$ After some difficulty relighting the furnace in the home, the furnace started and ran for about three hours as it warmed the mobile home. ${ }^{36}$ When one of the tenants lit a cigarette, a large gas explosion occurred due to a propane gas leak. ${ }^{37}$

Among other things, the injured plaintiffs claimed Empire Gas was strictly liable for their injuries because the propane gas and odorant it "manufactured and/or distributed and/or offered for sale and use" was unreasonably dangerous

\section{Id.}

26. Id. Perhaps because there was insufficient evidence to suggest Big Lots was the principal distributor or seller, the court never addressed whether it was able to acquire jurisdiction over the manufacturer of the allegedly defective coffee maker. Had it reached the issue, however, this too should have been another bar to the plaintiff's manufacturing defect claims against the seller because the court previously held jurisdiction over the manufacturer, but the manufacturer had settled and been dismissed from the case by the time the court issued its decision.

27. 37 N.E.3d 514 (Ind. Ct. App. 2015), trans. denied, 43 N.E.3d 1278 (Ind. 2016).

28. Id. at 523-24.

29. Id. at 518 .

30. Id.

31. Id.

32. $I d$.

33. Id.

34. $I d$.

35. Id.

36. Id.

37. Id. 
and defective. ${ }^{38}$ Empire Gas, however, argued it was merely a gas retailer and therefore could not be strictly liable under the IPLA because it was not a manufacturer. ${ }^{39}$ The court acknowledged strict liability under the IPLA only applied to manufacturers or those deemed to be manufacturers under the Act. ${ }^{40}$ The evidence before the court established Empire Gas sold and distributed propane. ${ }^{41}$ The odorant added to the propane was not added by Empire Gas, but was infused by the "manufacturer" prior to delivery to Empire Gas. ${ }^{42}$ Thus, the court concluded Empire Gas was a retail seller, not a manufacturer under the IPLA, and therefore not subject to strict liability. ${ }^{43}$

Big Lots and Mauck are two more decisions in a long line of recent cases consistently holding strict liability under Indiana Code section 34-20-2-3 is not a viable claim against retail sellers unless the seller is also the manufacturer or deemed to be a manufacturer under the IPLA.

\section{B. Physical Harm Caused by a Product}

For purposes of the IPLA, ““[p]hysical harm' ... means bodily injury, death, loss of services, and rights arising from any such injuries, as well as sudden, major damage to property." 44 It "does not include gradually evolving damage to property or economic losses from such damage." 45 A "product" is "any item or good that is personalty at the time it is conveyed by the seller to another party," but not a "transaction that, by its nature, involves wholly or predominantly the sale of a service rather than a product." ${ }^{, 46}$ Although the 2015 survey period did not include any cases further refining the concept of "physical harm caused by a product," several recent cases have done so. ${ }^{47}$

38. Id. at 523 .

39. Id. at $519,523$.

40. Id. at 523. To support its decision, the court analyzed various definitions within the IPLA, including, for example, Indiana Code section 34-6-2-77.

41. Id.

42. Id.

43. Id. at 523-24.

44. IND. CODE $\S 34-6-2-105$ (a) (2016).

45. Id. § 36-6-2-105(b).

46. Id. § 34-6-2-114(a)-(b).

47. See, e.g., Bell v. Par Pharm. Cos., No. 1:11-CV-01454-TWP-MJD, 2013 WL 2244345 (S.D. Ind. May 21, 2013); Barker v. CareFusion 303, Inc., No. 1:11-CV-00938-TWP-DKL, 2012 WL 5997494 (S.D. Ind. Nov. 30, 2012); Hathaway v. Cintas Corp. Servs., Inc., 903 F. Supp. 2d 669 (N.D. Ind. 2012); Pentony v. Valparaiso Dep't of Parks \& Recreation, 866 F. Supp. 2d 1002 (N.D. Ind. 2012); Miceli v. Ansell, Inc., 23 F. Supp. 2d 929, 932 (N.D. Ind. 1998); Fleetwood Enters., Inc. v. Progressive N. Ins. Co., 749 N.E.2d 492, $493-94$ (Ind. 2001); GuideOne Ins. Co. v. U.S. Water Sys., Inc., 950 N.E.2d 1236, 1244 (Ind. Ct. App. 2011). 


\section{Defective and Unreasonably Dangerous}

IPLA liability only extends to products that are in "defective condition," 48 which exists if the product, at the time it is conveyed by the seller to another party, is: "(1) not contemplated by reasonable persons among those considered expected users or consumers of the product; and (2) that will be unreasonably dangerous to the expected user or consumer when used in reasonably expectable ways of handling or consumption. ${ }^{, 49}$ Both are threshold proof requirements. ${ }^{50}$

Indiana claimants may prove a product is in a "defective condition" by asserting one or any combination of the following three theories: (1) the product has a defect in its design ("design defect"); (2) the product lacks adequate or appropriate warnings ("warning defect"); or (3) the product has a defect that is the result of a problem in the manufacturing process ("manufacturing defect"). ${ }^{51}$ An unreasonably dangerous product under the IPLA is one that "exposes the user or consumer to a risk of physical harm . . . beyond that contemplated by the ordinary consumer who purchases [it] with the ordinary knowledge about the product's characteristics common to the community of consumers." injures in a fashion that is objectively known to the community of product consumers, it is not unreasonably dangerous as a matter of law. ${ }^{53}$ Courts in Indiana have been fairly active in recent years when it comes to dealing with concepts of unreasonable danger and causation in Indiana product liability actions. ${ }^{54}$

48. IND. CODE $\S 34-20-2-1$.

49. Id. § 34-20-4-1.

50. See Baker v. Heye-Am., 799 N.E.2d 1135, 1140 (Ind. Ct. App. 2003) (“[U]nder the IPLA, the plaintiff must prove that the product was in a defective condition that rendered it unreasonably dangerous.").

51. See First Nat'l Bank \& Trust Corp. v. Am. Eurocopter Corp. (Inlow II), 378 F.3d 682, 689 (7th Cir. 2004); Westchester Fire Ins. Co. v. Am. Wood Fibers, Inc., No. 2:03-CV-178-TS, 2006 WL 752584, at *5 (N.D. Ind. Oct. 31, 2006); Baker, 799 N.E.2d at 1140.

Although claimants are free to assert any of the three theories, or a combination, for proving that a product is in a "defective condition," the IPLA provides explicit statutory guidelines for identifying when products are not defective as a matter of law. Indiana Code section 34-20-4-3 provides that "[a] product is not defective under [the IPLA] if it is safe for reasonably expectable handling and consumption. If an injury results from handling, preparation for use, or consumption that is not reasonably expectable, the seller is not liable under [the IPLA].” IND. CODE $§ 34-20-4-3$ (2013). In addition, "[a] product is not defective under [the IPLA] if the product is incapable of being made safe for its reasonably expectable use, when manufactured, sold, handled, and packaged properly." Id. § 34-20-4-4.

Joseph R. Alberts et al., Survey of Recent Developments in Indiana Product Liability Law, 47 IND. L. REV. 1129, 1133-34 n.45 (2014).

52. IND. CODE § 34-6-2-146; see also Baker, 799 N.E.2d at 1140.

53. Baker, 799 N.E.2d at 1140; see also Moss v. Crosman Corp., 136 F.3d 1169, 1174-75 (7th Cir. 1998).

54. Stuhlmacher v. Home Depot U.S.A., Inc., No. 2:10-CV-00467-JTM-APR, 2013 WL 
The IPLA, and specifically Indiana Code section 34-20-2-2, imposes a negligence standard in all product liability claims relying upon a design or warning theory to prove a product is in a defective condition:

[I]n an action based on an alleged design defect in the product or based on an alleged failure to provide adequate warnings or instructions regarding the use of the product, the party making the claim must establish that the manufacturer or seller failed to exercise reasonable care under the circumstances in designing the product or in providing the warnings or instructions. ${ }^{55}$

Accordingly, the term "strict" liability is no longer applicable in design and warning cases to the extent the term "strict" connotes the imposition of liability without regard to fault or the exercise of reasonable care. ${ }^{56}$ The IPLA contemplates the traditional type of "strict" liability (without fault or proof of negligence) only for so-called "manufacturing" defects-those that arise "in the manufacture and preparation of the product." "F7 For manufacturing defects, liability can be established even if the seller has "exercised all reasonable care."

Although the IPLA has for nearly twenty years made clear "strict" liability applies only in cases involving alleged manufacturing defects, some courts have been slow to recognize that concept. ${ }^{59}$ A misleading short title in the Burns Indiana Statutes Annotated compendium also may be contributing to some of the confusion in this area. ${ }^{60}$ In the 1998 Replacement Volume, the Burns editors

3201572 (N.D. Ind. June 21, 2013); Bell v. Par Pharm. Cos., No. 1:11-CV-01454-TWP-MJD, 2013 WL 2244345, at*1 (S.D. Ind. May 21, 2013); Beasley v. Thompson/Center Arms Co., No. 2:11CV-3-WTL-WGH, 2013 WL 968234 (S.D. Ind. Mar. 12, 2013); Hathaway v. Cintas Corp. Servs., Inc., 903 F. Supp. $2 d 669$ (N.D. Ind. 2012); Roberts v. Menard, Inc., No. 4:09-CV-59-PRC, 2011 WL 1576896 (N.D. Ind. Apr. 25, 2011); Price v. Kuchaes, 950 N.E.2d 1218, 1232-33 (Ind. Ct. App. 2011).

55. IND. CODE $\S 34-20-2-2$. Just like a claimant advancing any other type of negligence theory, a claimant advancing a product liability design or warning defect theory must meet the traditional negligence elements: duty, breach, injury, and causation. See Kovach v. Caligor Midwest, 913 N.E.2d 193, 197-99 (Ind. 2009).

56. IND. CODE $§ 34-6-2-2(1)$.

57. Id.; see also Mesman v. Crane Pro Servs., 409 F.3d 846, 849 (7th Cir. 2008); First Nat'1 Bank \& Tr. Corp. v. Am. Eurocopter Corp. (Inlow II), 378 F.3d 682, 689 n.4 (7th Cir. 2004); Conley v. Lift-All Co., No. 1:03-CV-1200-DFH-TAB, 2005 WL 1799505, at *6 (S.D. Ind. July 25, 2005); Bourne v. Marty Gilman, Inc., No. 1:03-CV-1375-DFH-VSS, 2005 WL 1703201, at*3 (S.D. Ind. 2005).

58. IND. CODE § 34-6-2-2(1). "Strict” liability for defects "in manufacturing and preparation" is also subject to the additional requirement that the "user or consumer has not bought the product from or entered into any contractual relation with the seller." Id. § 34-6-2-2(2).

59. See, e.g., Whitted v. Gen. Motors Corp., 58 F.3d 1200, 1206 (7th Cir. 1995); Vaughn v. Daniels Co., 841 N.E.2d 1133, 1138-39 (Ind. 2006); Warriner v. DC Marshall Jeep, 962 N.E.2d 1263 (Ind. Ct. App. 2012).

60. IND. CODE $\S 34-20-2-2$. 
inserted a short title for Indiana Code section 34-20-2-2, entitled, "Strict liability - Design defect." ${ }^{\text {"61 }}$ That short title unfortunately makes it appear to some readers as though strict liability applies either to the entire section (and thereby all three theories for proving defectiveness) or, at the very least, to design defect claims. ${ }^{62}$ Neither is accurate because, as noted above, a close reading of the statute reveals "strict" liability (liability without fault or proof of negligence) applies only to cases involving manufacturing defect theories and not to cases alleging either design or warning theories. ${ }^{63}$ Incidentally, the West editors did not use the same short title in the West's Annotated Indiana Code, choosing instead to use a more accurate short title styled, "Exercise of reasonable care; privity." ${ }^{64}$ In Jones $v$. Horseshoe Casino ${ }^{65}$ Chief Judge Simon recognized the unfortunate Burns short title of Indiana Code section 34-20-2-2 can be confusing: "This statute is confusing in that it applies a negligence standard to a claim it calls 'strict liability.", 66

The 2015 case of Heritage Operating LP v. Mauck, provides a good illustration of how confusion surrounding the "strict" liability concept can profoundly affect the outcome of a case ${ }^{67}$ As described briefly above, the Mauck court resolved the manufacturer/seller issue as a matter of law, but in doing so, it presumed there was an operative IPLA-based "strict liability" claim. ${ }^{68} \mathrm{~A}$ close reading of the decision reveals the plaintiffs' only real IPLA-based defect theory alleged an inadequate warning. ${ }^{69}$ The decision does not indicate plaintiffs were pursuing any design defect claims, nor did the plaintiffs appear to have asserted a "manufacturing defect" claim by contending the natural gas product itself suffered from some kind of problem or glitch in the manufacturing process. ${ }^{70}$ The plaintiffs appeared to have recognized natural gas is what it is, and they did not appear to have taken any issue with the process of refining or producing it. ${ }^{71}$ Accordingly, there was no "strict" liability theory Indiana Code section 34-20-2-2

61. Id.

62. See, e.g., Whitted, 58 F.3d at 1206; Vaughn, 841 N.E.2d at 1138-39; Warriner, 962 N.E.2d 1263.

63. IND. CODE $\S 34-6-2-2(1)$.

64. IND. CODE § 34-20-2-2. The Indiana General Assembly originally codified in 1995 the language now found in Indiana Code section 34-20-2-2. That language was subsequently renumbered in 1998 as part of a reorganization of Title 34. Neither the 1995 enactment nor the 1998 recodification, as published by the Indiana General Assembly, included any section short title for the particular section involved here.

65. No. 2:15-cv-00014-PPS-PRC, 2015 WL 3407872 (N.D. Ind. May 27, 2015).

66. $I d$. at $* 2$.

67. Heritage Operating LP v. Mauck, 37 N.E.3d 514 (Ind. Ct. App. 2015), trans. denied, 43 N.E.3d 1278 (Ind. 2016).

68. Id. at 522-25.

69. Id. at 520 .

70. Id. at 519 .

71. Id. 
would allow in the Mauck case. ${ }^{72}$ As discussed above, to the extent "strict" liability is a term associated with the concept of liability without regard to fault or proof of negligence, it is not a doctrine the IPLA recognizes as applicable to inadequate warning theories. ${ }^{73}$ It is, therefore, peculiar that the Mauck court took such great pains to reject the Indiana Supreme Court's venerable Webb v. Jarvis three-part duty analysis applicable to negligence cases in favor of a separate duty analysis arising out of an older line of non-IPLA cases that treated natural gas as "a dangerous instrumentality." "That the Mauck court was under the impression an IPLA-based warnings defect negligence case is functionally the same as a traditional "strict" liability case might help explain why it rejected the Webb test in favor of a special rule when natural gas is the "product" at issue. ${ }^{75}$

Courts in Indiana frequently addressed in recent years concepts of unreasonable danger and causation in Indiana product liability actions. In 2015, the Seventh Circuit, in Piltch v. Ford Motor Co., again addressed a causation issue, though in the unique context of res ipsa loquitur doctrine. ${ }^{76}$ The plaintiffs in Piltch were injured in a 2007 car accident when the air bags in their Mercury Mountaineer failed to deploy. ${ }^{77}$ A year earlier, the Mountaineer had been involved in another car accident in which the air bags did not deploy. ${ }^{78}$ The vehicle was repaired after the 2006 accident, and the plaintiffs assumed the air bags were reset during that repair process. ${ }^{79}$ In 2009 , one year before the lawsuit was filed, the plaintiffs sold the Mountaineer. ${ }^{80}$ The car's "black box" was wiped clean after the sale; accordingly, no electronic data regarding either the 2006 or 2007 accident was retained. ${ }^{81}$ The plaintiffs sued Ford for damages arising from the 2007 accident, but they failed to support their allegations of design and manufacturing defect with expert testimony. ${ }^{82}$

The court noted in addition to proving the existence of a defect, the plaintiffs also had to prove causation. ${ }^{83}$ The plaintiffs' claims rested in part on the crashworthiness doctrine, which operates as an expansion of proximate cause and "imposes liability for design defects that enhance injuries from a collision, but did not cause the collision in the first place." ${ }^{~} 4$ The plaintiffs failed to provide expert testimony on the issue of proximate cause, and so "a lay juror could not

72. IND. CODE $\S 34-6-2-2(1)(2016)$.

73. Heritage Operating $L P, 37$ N.E.3d at 519.

74. Id. at 521 (quoting Palmer \& Sons Paving, Inc. v. N. Ind. Pub. Serv. Co., 758 N.E.2d 550, 554 (Ind. Ct. App. 2001)).

75. Id. at 522-25.

76. Piltch v. Ford Motor Co., 778 F.3d 628 (7th Cir. 2015).

77. Id. at 631 .

78. Id. at 630 .

79. Id. at 631 .

80. Id.

81. Id.

82. Id.

83. Id. at 633 .

84. Id. at 633-34. 
distinguish between the injuries caused by the collision and the enhanced injuries caused by the air bags' failure to deploy without engaging in pure speculation." ${ }^{85}$ The plaintiffs also attempted to prove their case by invoking the doctrine of res ipsa loquitur, which allows a jury to infer a defect based on circumstantial evidence. ${ }^{86}$ A plaintiff asserting res ipsa loquitur must prove the component alleged to have caused the injury was under the "exclusive control of the defendant at the time of injury," and the accident is not one that normally occurs if the defendant is exercising proper care ${ }^{87}$ The court found there were other possible explanations for the air bags' failed deployment-most notably, the possibility the air bag mechanism was not reset after the car's 2006 accident. ${ }^{88}$ The plaintiffs designated no evidence to rule out this possibility. ${ }^{89}$ Thus, the jury could only speculate as to the cause of the air bag failure, making this case inappropriate for application of the res ipsa loquitur doctrine. ${ }^{90}$

\section{Decisions Involving Specific Defect Theories}

1. Warning Defect Theory.-The IPLA contains a specific statutory provision covering the warning defect theory:

A product is defective ... . if the seller fails to: (1) properly package or label the product to give reasonable warnings of danger about the product; or (2) give reasonably complete instructions on proper use of the product; when the seller, by exercising reasonable diligence, could have made such warnings or instructions available to the user or consumer. ${ }^{91}$

For a cause of action to attach in failure to warn cases, the "unreasonably dangerous" inquiry is similar to the requirement that the danger or alleged defect be latent or hidden. ${ }^{92}$

Courts interpreting Indiana warning defect theories have been quite active in the past decade or so. ${ }^{93}$ This Survey will focus on two warning defect cases, both of which are federal cases arising out of the Northern District of Indiana. ${ }^{94}$ The

\section{Id. at 634 .}

86. Id.

87. Id.

88. Id. at 635 .

89. Id.

90. Id.

91. IND. CODE $§ 34-20-4-2$ (2016).

92. See First Nat'l Bank \& Trust Corp. v. Am. Eurocopter Corp. (Inlow II), 378 F.3d 682, 690 n.5 (7th Cir. 2004).

93. See, e.g., Weigle v. SPX Corp., 729 F.3d 724 (7th Cir. 2013); Hartman v. Ebsco Indus., Inc., No. 3:10-CV-528-TLS, 2013 WL 5460296 (N.D. Ind. Sept. 30, 2013); Stuhlmacher v. Home Depot U.S.A., Inc., No. 2:10-CV-00467-JTM-APR, 2013 WL 3201572 (N.D. Ind. June 21, 2013); Tague v. Wright Med. Tech., Inc., No. 4:12-CV-13-TLS, 2012 WL 1655760 (N.D. Ind. May 10, 2012); Hathaway v. Cintas Corp. Servs., Inc., 903 F. Supp. 2d 669 (N.D. Ind. 2012).

94. See Simmons v. Philips Elecs. N.A. Corp., No. 2:12-CV-39-TLS, 2015 WL 1418772 
first case, Shelter Ins. Cos. v. Big Lots Stores, Inc. ${ }^{95}$ is discussed briefly above in section I.A. The case involved a subrogation claim brought by an insurer for a fire caused by a Kenmore coffee maker alleged to be defective. ${ }^{96}$ In addition to the strict liability claims previously discussed, the insurer claimed Big Lots failed to provide adequate warnings or instructions. ${ }^{97}$ To support this claim, the insurer argued the wiring and plug blade in the coffee maker retrieved from the home after the fire were different than those in an exemplar Kenmore coffee maker of the same model. ${ }^{98}$ Plaintiff argued Big Lots sometimes sold distressed merchandise and the coffee maker which allegedly caused the fire was not in the same condition as when it left the manufacturer. ${ }^{99}$ Thus, plaintiff argued, Big Lots had a duty to warn purchasers the coffee maker was "a distressed product that might be in a different condition than a Kenmore coffee maker sold by the manufacturer." 100

The court rejected the argument noting the purchaser received an owner's manual with the coffee maker. ${ }^{101}$ Even though none of the warnings in the manual were in the record, the court opined there was no evidence Big Lots knew or should have known of any modification of the coffee maker, or that any modification would require any different warning or instructions than those contained within the owner's manual. ${ }^{102}$ Quoting Ford Motor Co. v. Rushford,${ }^{103}$ the court noted in the absence of actual or constructive knowledge of a product modification, a seller's duty to warn is discharged where it provides a manufacturer's warnings. ${ }^{104}$ "In other words absent special circumstances, if the manufacturer provides adequate warnings of the danger of its product and the seller passes this warning along to the buyer or consumer, then the seller has no obligation to provide additional warnings." ${ }^{105}$ The court concluded the only evidence before it was the coffee maker alleged to be defective was different than the exemplar. ${ }^{106}$ The insurer had not identified any specific dangers or offered any evidence the warnings in the owner's manual were inadequate. ${ }^{107}$ Finally, there was no evidence Big Lots knew or should have known any differences existed in the coffee maker or these differences presented risks not covered in the owner's

(N.D. Ind. Mar. 27, 2015); Shelter Ins. Cos. v. Big Lots Stores, Inc., No. 3:12-CV-433-JVB, 2014 WL 4494382 (N.D. Ind. Sept. 10, 2014).

95. Shelter Ins. Cos., 2014 WL 4494382.

96. Id. at *1.

97. Id. at $* 2$.

98. Id.

99. Id.

100. $I d$.

101. $I d$.

102. Id. at *2-3.

103. 868 N.E.2d 806, 811 (Ind. 2007).

104. Shelter Ins. Cos., 2014 WL 4494382, at *2.

105. Id. at *3 (quoting Ford Motor Co., 868 N.E.2d at 811).

106. Id.

107. Id. 
manual. ${ }^{108}$ As such, the insurer's warning defect claim failed. ${ }^{109}$

The second warning defect case, Simmons v. Philips Electronics N.A. Corp. ${ }^{110}$ involved a twenty-seven-inch cathode ray tube television and resulting fatal injury to a toddler when the television tipped over and landed on him. ${ }^{111}$ The plaintiffs argued the television at issue was defective because the defendant had failed to warn them of or provide adequate instructions about the danger the television could tip over on top of children if placed on top of a dresser. ${ }^{112}$ The court first analyzed whether a duty to warn existed and determined one did. ${ }^{113}$ The court opined a manufacturer has a duty to warn of latent dangerous characteristics of a product even if the product itself does not contain a defect. ${ }^{114}$ Further, a duty to warn exists if a misuse is reasonably expected or if the manufacturer knows the product is being widely misused. ${ }^{115}$

The television manufacturer argued the danger of a television tipping over was an "open and obvious" danger. ${ }^{116}$ In short, the television was heavy, a characteristic that was not hidden and was easily observable. ${ }^{117}$ Thus, it had no duty to warn. ${ }^{118}$ The court rejected the argument acknowledging some cases were so one-sided there was no possibility a plaintiff could recover, but such was not the case. ${ }^{119}$ The evidence designated by the plaintiffs suggested the tip-over hazard was known by the industry, but was not known or appreciated by the average consumer. ${ }^{120}$ Further, at least one industry group in which the manufacturer participated recognized the tip-over hazard and engaged in consumer education efforts to make consumers aware of the danger posed by cathode ray televisions tipping-over on top of and injuring small children. ${ }^{121}$ Thus, the tip-over use (or misuse) was reasonably foreseeable by the manufacturer. ${ }^{122}$ The court could not conclude, based on the evidence before it, the plaintiffs could not prevail on their warning claims. ${ }^{123}$ The court also found

108. Id.

109. Id.

110. No. 2:12-CV-39-TLS, 2015 WL 1418772 (N.D. Ind. Mar. 27, 2015).

111. Id. at *1-2.

112. Id. at *7.

113. Id. at *7-8. Citing American Optical Co. v. Weidenhamer, 457 N.E.2d 181, 187 (Ind. 1983), the Indiana Supreme Court acknowledged, without proof of a dangerous instrumentality or proof of a defect or improper design making an otherwise harmless instrument dangerous, no duty to warn exists. $I d$. at $* 7$.

114. Id. (citing Nat. Gas Odorizing, Inc. v. Downs, 685 N.E.2d 155, 160 (Ind. Ct. App. 2009)).

115. Id. (citing Leon v. Caterpillar Indus., Inc., 69 F.3d 1326, 1343 (7th Cir.1995)).

116. Id. at $* 8$.

117. Id.

118. Id.

119. Id.

120. $I d$.

121. Id. at $* 2$.

122. Id. at *9.

123. Id. 
a question existed as to the adequacy of the warnings provided by the manufacturer, because the manufacturer's safety instructions did not expressly reference the risk to children created by the alleged tip-over hazard and the warnings on the television itself only referenced the risk of electric shock. ${ }^{124}$ The court held because adequacy of warnings was classically a question for a jury, it could not enter summary judgment for the manufacturer. ${ }^{125}$

2. Design Defect Theory.- State and federal courts in Indiana substantively addressed design defect theories in several recent cases. ${ }^{126}$ The 2015 survey period added a couple more to the mix. The first case, Simmons v. Philips Electronics N.A. Corp. ${ }^{127}$ discussed at length in section I.D.1, involved a design defect theory in addition to the warnings defect theory addressed above. The design defect theory advanced two primary claims. ${ }^{128}$ First, the plaintiffs claimed because the television could tip-over so easily, the manufacturer should have included a tethering device or other mounting hardware. ${ }^{129}$ Second, the television should have been designed to withstand a "greater application of force," i.e., it should have been designed so it was more stable and harder to tip over. ${ }^{130}$

The court reasoned that for the plaintiffs to defeat the defendant's summary judgment motion, they had to show the product was both defective and also "unreasonably dangerous." 131 Establishing a defect in the product's design focused on the product. ${ }^{132}$ Establishing the unreasonably dangerous requirement, however, focused on the "reasonable expectations of the consumer." 133 Finally, the plaintiffs must also be able to establish the existence of a feasible alternative design. ${ }^{134}$

The court found the plaintiffs had marshaled sufficient evidence to establish a defect in the product's design by the use of expert testimony. ${ }^{135}$ Plaintiffs' expert opined that depending upon how and where force was applied at or near the top of the television, ten to twelve and a half pounds of force would either

124. $I d$. at $* 10$.

125. Id.

126. See, e.g., Weigle v. SPX Corp., 729 F.3d 724 (7th Cir. 2013); Lapsley v. Xtek, Inc., 689 F.3d 802 (7th Cir. 2012); Mesman v. Crane Pro Servs., Inc., 409 F.3d 846 (7th Cir. 2005); Hathaway v. Cintas Corp. Servs., Inc., 903 F. Supp. 2d 669 (N.D. Ind. 2012) (discussing design defects and products liability); Green v. Ford Motor Co., 942 N.E.2d 791 (Ind. 2011); TRW Vehicle Safety Sys., Inc. v. Moore, 936 N.E.2d 201 (Ind. 2010).

127. Simmons, 2015 WL 1418772.

128. Id. at *10-11.

129. Id. at *11.

130. Id. at $* 10$.

131. Id. (citing McMahon v. Bunn-O-Matic Corp., 150 F.3d 651, 657 (7th Cir. 1998)).

132. Id.

133. Id.

134. Id. ("Indiana [law] requires the plaintiff to show that another design not only could have prevented the injury but also was cost-effective under general negligence principles." (quoting Whitted v. Gen. Motors Corp., 58 F.3d 1200, 1206 (7th Cir. 1995))).

135. Id. at *10-11. 
cause the television to begin to tip or make it tip over altogether. ${ }^{136}$ Further, an industry proposal to ameliorate tipping hazards would require a television to withstand a force of $20 \%$ of its weight without tipping, and the television at issue could not pass this requirement. ${ }^{137}$

As it related to satisfying the unreasonably dangerous requirement, the manufacturer argued the television was not unreasonably dangerous because the risk it might topple over when placed on top of a dresser and pulled on was an open and obvious risk. ${ }^{138}$ As with the warning defect claim, however, the court again determined the plaintiffs had presented sufficient evidence to suggest the alleged risk was not open and obvious to the average consumer. ${ }^{139}$ When the court viewed the evidence in the light most favorable to the plaintiffs, it could not grant the manufacturer's motion for summary judgment. ${ }^{140}$

Another case, Piltch v. Ford Motor Co. ${ }^{141}$ is also worthy of a brief mention. The plaintiffs in Piltch were injured when their Mercury Mountaineer struck a wall and the air bags failed to deploy. ${ }^{142}$ The complaint alleged the Mountaineer's air bags suffered from both design and manufacturing defects. ${ }^{143}$ The court's key dispositive analysis, which is addressed more fully below in section II, centered around the lack of credible expert testimony necessary to support the design defect claim. ${ }^{144}$ The authors note here, however, the court also concluded claimants asserted, but failed to produce, any alternative airbag designs as the IPLA requires. ${ }^{145}$

\section{E. Regardless of the Substantive Legal Theory}

The Indiana General Assembly carved out a limited exception to the IPLA's exclusive remedy in Indiana Code section 34-20-1-2. ${ }^{146}$ The exception occurs where the defendant would otherwise satisfy the IPLA's definition of "seller" and the harm suffered by the claimant is not sudden, major property damage, personal injury, or death. ${ }^{147}$ When these criteria are met, recovery theories can constitute

136. Id. at $* 10$.

137. $I d$. at $* 11$.

138. Id.

139. Id.

140. Id. at $* 12$.

141. 778 F.3d 628 (7th Cir. 2015).

142. Id. at 630 .

143. Id. at 632 .

144. Id. at 632-33.

145. Id. at 632 .

146. For purposes of the IPLA, ““[m] anufacturer' ... means a person or an entity who designs, assembles, fabricates, produces, constructs, or otherwise prepares a product or a component part of a product before the sale of the product to a user or consumer." IND. CODE §34-6-2-77(a) (2016). "'Seller' ... means a person engaged in the business of selling or leasing a product for resale, use, or consumption.” Id. § 34-6-2-136.

147. See id. § 34-20-1-2. 
the "other" actions not limited by Indiana Code section 34-20-1-2. ${ }^{148}$ Indiana Code section 34-20-1-2 does not permit any claim against a "seller" that involves purely economic losses sounding on the common law of contracts, warranty, or the Uniform Commercial Code ("UCC"), or gradually developing property damage where all elements needed to demonstrate a typical contract-like claim are met. ${ }^{149}$ In practical effect, application of the economic loss doctrine to tortbased warranty and negligence claims is simply another way of giving effect to the "regardless of the substantive legal theory" language in Indiana Code section 34-20-1-1. ${ }^{150}$ When claims for "physical harm" caused by a product arise, the exclusive IPLA-based cause of action subsumes remedies found in common law or the UCC. ${ }^{151}$ Some courts have referred to the subsuming of those claims as "merger." " R2 Regardless of terminology, "merged" or "subsumed" claims fail. The IPLA controls those claims, and only IPLA-sanctioned recovery (claims asserting either manufacturing, design, or warning defects) survive. ${ }^{153}$ The best examples of claims that should be subsumed are those seeking recovery for common law negligence not rooted in design or warning defects and tort-based breaches of warranty. Several recent cases recognizing the "merger" concept simply dismiss the common law or warranty claims not contemplated by the IPLA. ${ }^{154}$ Other decisions refused to outright dismiss the claims, preferring to "merge" them into surviving IPLA claims. ${ }^{155}$ An Indiana federal case during the 2015 survey period,

148. Id.

149. Such a reading of the statute is consistent with the "economic loss doctrine" cases that preclude a claimant from maintaining a tort-based action against a defendant when the only loss sustained is an economic as opposed to a "physical" one. See, e.g., Gunkel v. Renovations, Inc., 822 N.E.2d 150, 151 (Ind. 2005); Fleetwood Enters., Inc. v. Progressive N. Ins. Co., 749 N.E.2d 492, 495-96 (Ind. 2001); Progressive Ins. Co. v. Gen. Motors Corp., 749 N.E.2d 484, 488-89 (Ind. 2001); Corry v. Jahn, 972 N.E.2d 907 (Ind. Ct. App. 2012).

150. IND. CODE $\S 34-20-1-1$.

151. Gunkel, 822 N.E.2d at 152; Progressive, 749 N.E.2d at 495.

152. See, e.g., Atkinson v. P\&G-Clairol, Inc., 813 F. Supp. 2d 1021, 1027 (N.D. Ind. 2011); Ganahl v. Stryker Corp., No. 1:10-cv-1518-JMS-TAB, 2011 WL 693331, at*3 (S.D. Ind. Feb. 15, 2011).

153. See, e.g., Atkinson, 813 F. Supp. 2d 1021.

154. See, e.g., Stuhlmacher v. Home Depot U.S.A., Inc., No. 2:10-CV-00467-JTM-APR, 2013 WL 3201572, at*15-16 (N.D. Ind. June 21, 2013) (merging common law negligence claims into IPLA-based claims and dismissing tort-based breach of implied warranty claims); Hathaway v. Cintas Corp. Servs, Inc., 903 F. Supp. 2d 669, 673 (N.D. Ind. 2012).

155. See Lautzenhiser v. Coloplast A/S, No. 4:11-CV-86-RLY-WGH, 2012 WL 4530804 (S.D. Ind. Sept. 29, 2012). The court in Lautzenhiser recognized the concept that tort-based implied warranty claims should be "merged" with the IPLA-based claims, but chose not to dismiss the tortbased implied warranty claims. Id. at *4-5. The court first concluded the tort-based warranty claims "survive[d]" the defendant's motion to dismiss because vertical privity is not required. Id. at *5. Instead of dismissing those claims as did the court in Hathaway, the Lautzenhiser court "merged" them with the "ordinary negligence," "defective design," and "failure to warn" claims. $I d$. Some recent cases disregarded the IPLA's exclusive remedy where a product causes "physical harm" and 
took that route. In Lyons v. Leatt Corp. ${ }^{156}$ the plaintiff sued the manufacturer of a Moto GPX Sport Leatt-Brace, asserting, among other theories of recovery, "strict liability," breach of warranty, and negligence. ${ }^{157}$ As part of a written order on the manufacturer's motion to dismiss, Judge Springmann recognized the plaintiff's common law negligence and breach of express and implied warranty claims should be merged into his IPLA-based product liability claims. ${ }^{158}$

\section{Opinion Witness Testimony in Product Liability Cases}

The survey period yielded three significant decisions discussing the importance of expert testimony in product liability cases. In the first case, Piltch v. Ford Motor Co., ${ }^{159}$ the plaintiffs were injured when their Mercury Mountaineer struck a wall and the air bags failed to deploy. The complaint alleged the Mountaineer's air bags suffered from both design and manufacturing defects. ${ }^{160}$ Although the IPLA claims asserted in Piltch involved manufacturing and design defects theories, the court addressed and disposed of the issues in a discussion it styled "[e]xpert [t]estimony." "161 Accordingly, the authors present the court's analysis in the same context here. Ford filed a motion for summary judgment alleging the plaintiffs failed to offer expert testimony in support of their theories and, without such expert testimony, plaintiffs could not prove their case. ${ }^{162} \mathrm{In}$ response, the plaintiffs argued expert testimony was not necessary because circumstantial evidence - in the form of the plaintiffs' testimony and the owner's manual-created a genuine issue of material fact. ${ }^{163}$ The district court granted the manufacturer's motion for summary judgment. ${ }^{164}$

On appeal, the Seventh Circuit noted expert testimony is "required when the issue is not within the understanding of a lay person." 165 The plaintiffs needed to present expert testimony on the design defect claim because a lay jury could not weigh the costs and benefits of an alternative air bag design, nor could a lay jury

allowed "users" or "consumers" to use common law theories of recovery where "physical harm" occurred against a "manufacturer" or "seller" in addition to IPLA sanctioned recovery options. See Ritchie v. Glidden Co., 242 F.3d 713, 726-27 (7th Cir. 2001); Vaughn v. Daniels Co., 841 N.E.2d 1133, 1141-42 (Ind. 2006); Kennedy v. Guess, Inc., 806 N.E.2d 776, 783-84 (Ind. 2004); Brosch v. K-Mart Corp., No. 2:08-CV-152, 2012 WL 3960787 (N.D. Ind. Sept. 10, 2012); Warriner v. DC Marshall Jeep, 962 N.E.2d 1263 (Ind. Ct. App. 2012); Deaton v. Robison, 878 N.E.2d 499, 501-03 (Ind. Ct. App. 2007).

156. No. 4:15-CV-17-TLS, 2015 WL 7016469 (N.D. Ind. Nov. 10, 2015).

157. Id. at $* 1$.

158. Id. at *2-3.

159. 778 F.3d 628 (7th Cir. 2015).

160. Id. at 631 .

161. Id. at 631-32.

162. Id.

163. Id. at 631.

164. Id.

165. Id. at 632 . 
determine whether an alternative air bag design would have prevented the plaintiffs' injuries. ${ }^{166}$ Similarly, the court concluded expert testimony was required on the manufacturing defect claim. $^{167}$ The plaintiffs claimed circumstantial evidence proved a manufacturing defect. ${ }^{168}$ Specifically, they argued the "Mountaineer's owner's manual establishe[d] the intended design of the air bags, and that the state of the air bags during and after the 2007 collision indicate[d] a departure from that intended design." 169 Although circumstantial evidence can create a genuine issue of material fact on a manufacturing defect claim, ${ }^{170}$ there was insufficient evidence to do so here. ${ }^{171}$ The plaintiffs offered only their own testimony regarding the state of the car after the collision; they did not preserve the Mountaineer or its blackbox after the collision, nor did they offer the testimony of a skilled witness who could "fill in some of these blanks." 172 Thus, "a lay person would be unable to discern whether the circumstances of the crash should have triggered air bag deployment or not." ${ }^{, 173}$ The Seventh Circuit affirmed the district court's order granting Ford's motion for summary judgment. ${ }^{174}$

The second case addressing the need for expert testimony in a product liability case is Leal v. TSA Stores, Inc. ${ }^{175}$ The plaintiff was injured when the handlebars on her bicycle came loose, causing her to fall. ${ }^{176}$ The bicycle was designed by East Coast Cycle Supply ("East Coast"), manufactured by a Chinese company, and sold by Sports Authority. ${ }^{177}$ The bicycle arrived at Sports Authority assembled, with the exception of the handlebars, front wheels, and pedals. ${ }^{178}$ The plaintiff sued multiple parties, including the designer, East Coast. ${ }^{179}$ In support of its motion for summary judgment, East Coast designated the expert affidavit of its president, who testified the handlebars came loose because of poor assembly_not a design or manufacturing defect. ${ }^{180}$ The plaintiff did not oppose this motion for summary judgment, nor did she offer an expert witness to counter East Coast's expert's opinion. ${ }^{181}$ The court noted an unopposed motion for summary judgment is not granted as a matter of course; rather, the court must still

166. Id.

167. Id. at 633 .

168. Id.

169. Id.

170. Id. (citing Cansler v. Mills, 765 N.E.2d 698 (Ind. Ct. App. 2002)).

171. Id.

172. Id.

173. Id.

174. Id. at 634 .

175. No. 2:13 CV 318, 2014 WL 7272751, at*1 (N.D. Ind. Dec. 17. 2014).

176. Id. at *2.

177. Id.

178. Id.

179. Id.

180. Id. at *3.

181. Id. 
evaluate whether the moving party has met its burden. ${ }^{182}$ Here, the plaintiff did not offer expert testimony, or any other evidence, in support of her argument that East Coast's bicycle design fell below the standard of care. ${ }^{183}$ In fact, she testified in her deposition she was unaware of how East Coast's design could have caused her injuries. ${ }^{184}$ East Coast, on the other hand, offered competent expert testimony in support of its argument the handlebars came loose due to an assembly problem. ${ }^{185}$ The court concluded summary judgment in favor of East Coast was appropriate because the plaintiff "ha[d] not even attempted to prove more than the 'mere assertion' in her Complaint that the design of the handlebars and stem were defective[]." "186

The third case dealing with expert testimony addressed the technical requirements for expert affidavits. In Simmons v. Philips Electronics North America Corp. ${ }^{187}$ the plaintiffs' ten-month-old child was killed when a television, which had been placed on a dresser, fell on him. ${ }^{188}$ Plaintiffs brought both design defect and failure to warn claims, specifically alleging the television was unstable and it should have borne a prominent tip-over warning. ${ }^{189}$ The manufacturer moved for summary judgment and supported its motion with an expert affidavit. ${ }^{190}$ The plaintiffs' opposition was supported by two expert affidavits. ${ }^{191}$

The plaintiffs moved to strike the manufacturer's expert affidavit on the grounds it contained hearsay and was unverified at the time it was filed. ${ }^{192} \mathrm{~W}$ ith regard to the hearsay argument, the court denied the motion to strike because " $[t]$ o the extent that any of the Defendant's evidence would be inadmissible if the Defendant were to offer them at trial, the Court will not consider them."193 Although the manufacturer's expert report was unsworn at the time of filing, the court noted the manufacturer corrected this deficiency in a timely manner. ${ }^{194}$ Thus, the court denied the motion to strike because the plaintiffs were not prejudiced. ${ }^{195}$

The manufacturer moved to strike portions of the plaintiffs' experts' affidavits on the grounds they supplemented earlier expert reports with new information; thus, the manufacturer was denied adequate notice of the experts'

182. Id. at $* 2$.

183. Id. at *3.

184. Id. at *3-4.

185. Id. at *4.

186. Id.

187. No. 2:12-CV-39-TLS, 2015 WL 1418772, at*1 (N.D. Ind. Mar. 27, 2015).

188. Id.

189. Id. at *3.

190. Id. at *4.

191. Id. at *4-5.

192. Id.

193. Id. at *4.

194. Id. at *5.

195. Id. 
opinions. ${ }^{196}$ The court disagreed, finding the plaintiffs' expert affidavits merely expanded and clarified "opinions previously disclosed in the expert reports."197 Accordingly, the court denied the manufacturer's motion to strike. ${ }^{198}$

\section{FEDERAL PREEMPTION}

The survey period presented two significant preemption decisions. The first case, McAfee v. Medtronic, Inc., ${ }^{199}$ focused on express preemption and involved an implantable defibrillator lead regulated by the Food and Drug Administration ("FDA"). As a condition to obtaining FDA approval for the lead, the manufacturer was required to report any "adverse events" to the FDA. ${ }^{200}$ In July 2006, the manufacturer reported fifteen adverse events to the FDA dating back to March 2006. ${ }^{201}$ The lead was implanted in the plaintiff eleven days after the manufacturer submitted its adverse events report to the FDA. ${ }^{202}$ The manufacturer recalled the device in October $2007 .{ }^{203}$ In 2010 , the plaintiff was injured when the lead malfunctioned. ${ }^{204}$ The plaintiff alleged multiple state law theories, including failure to warn, design defect, and manufacturing defect. ${ }^{205}$ The manufacturer moved to dismiss the complaint, arguing the claims were expressly preempted. ${ }^{206}$ The Medical Device Amendments ("MDA") ${ }^{207}$ to the Food Drug and Cosmetic Act ("FDCA") contain an express preemption provision that prevents states from establishing requirements that are "different from, or in addition to, any requirement" under the FDCA. ${ }^{208}$ The central question was whether the plaintiff's claims paralleled federal requirements, or whether they imposed different or additional requirements. ${ }^{209}$

First, the court addressed the plaintiff's failure to warn claim. ${ }^{210}$ If the claim was based on the manufacturer's "failure to file adverse event reports with the

196. Id.

197. Id.

198. Id.

199. No. 1:12-CV-417 RLM, 2015 WL 3617755, at*1 (N.D. Ind. June 4, 2015), on reconsideration, 2016 WL 2588807 (N.D. Ind. May 5, 2016).

200. Id.

201. Id.

202. $I d$.

203. $I d$.

204. Id.

205. Id. at $* 2$.

206. Id. The manufacturer also argued the plaintiff's claims were impliedly preempted under Buckman Co. v. Plaintiff's Legal Committee, 531 U.S. 341, 349 (2001). Id. at *4. The court summarily disposed of this argument, concluding the plaintiff's claims were not impliedly preempted because they were based on state tort law, not "fraud-on-the-agency." Id.

207. 21 U.S.C. $\S 360 \mathrm{k}(\mathrm{a})(2016)$.

208. McAfee, 2015 WL 3617755 , at *4 (quoting 21 U.S.C. $\S 360 \mathrm{k}(\mathrm{a})$ ).

209. $I d$.

210. $I d$. 
FDA and the duty to warn extends to third parties like the FDA under Indiana law," then the plaintiff's claim would not be preempted because it would parallel federal requirements. ${ }^{211}$ On the other hand, if the claim was based on the manufacturer's failure to "provide an additional warning to physicians about the risks" of the lead, then the claim would be preempted because it would impose a requirement in addition to the federal mandates. ${ }^{212}$ The court concluded the plaintiff "stated plausible claims for relief under state law based on an alleged failure to warn the FDA"; thus, the plaintiff's failure to warn claim survived the manufacturer's motion to dismiss. ${ }^{213}$ Less than a year later, however, the court reconsidered its ruling on this issue. ${ }^{214}$ In a 2016 order, the court found that its previous ruling failed to address whether the plaintiff had adequately pled the element of causation. ${ }^{215}$ The plaintiff's claim was based on adverse event reports that were filed with the FDA before the plaintiff's surgery; thus, any delay in reporting these incidents to the FDA could not have caused the harm. ${ }^{216}$ Because the plaintiff did not allege sufficient facts to demonstrate causation, the court granted the defendant's motion to reconsider and dismissed the plaintiff's failure to warn claim without prejudice. ${ }^{217}$

The court also addressed the plaintiff's design and manufacturing defect claims. ${ }^{218}$ These claims were not preempted "to the extent they [were] premised on a failure to comply with the FDCA, FDA regulations, or FDA-approved specifications and protocols set forth in premarket approval standards." 219 The plaintiff's complaint, however, did not adequately plead any violation of the aforementioned standards. ${ }^{220}$ In addition, the preemption doctrine barred plaintiff's design and manufacturing defect claims to the extent they sought to impose liability on the manufacturer even if the manufacturer was in compliance with FDA mandates. ${ }^{221}$ Any such claim would impose requirements in addition to the federal requirements. ${ }^{222}$ The court dismissed the design and manufacturing defect claims without prejudice. ${ }^{223}$

The second preemption case, Ossim v. Anulex Technologies, ${ }^{224}$ focused on implied preemption. The medical device at issue was marketed to spinal surgeons

211. Id. at *5.

212. Id.

213. Id.

214. McAfee v. Medtronic, Inc., No. 1:12-CV-417 RLM, 2016 WL 2588807 (N.D. Ind. May $5,2016)$.

215. Id. at *2.

216. Id. at *3.

217. Id. at $* 7$.

218. McAfee, 2015 WL 3617755, at *5-6.

219. Id. at *6.

220. Id.

221. $I d$.

222. Id.

223. $I d$.

224. No. 1:14-cv-00254-TWP-DKL, 2014 WL 4908574, at*2 (S.D. Ind. Sept. 30, 2014). 
for use in disc surgeries. ${ }^{225}$ The manufacturer did not obtain the requisite FDA approval before marketing the device for this purpose. ${ }^{226}$ The device was implanted during the plaintiff's spinal surgery, and he suffered complications. ${ }^{227}$ The plaintiff brought a product liability action based in part on the manufacturer's failure to obtain FDA approval for the device. ${ }^{228}$ The manufacturer argued the plaintiff was, in effect, bringing a fraud-on-the-FDA claim; thus, the claim was impliedly preempted ${ }^{229}$ under Buckman Co. v. Plaintiffs' Legal Committee. ${ }^{230}$ The court disagreed..$^{231}$ The plaintiff was not alleging fraud on the FDA; rather, his state law tort claims were premised on an alleged violation of federal law. ${ }^{232}$ Because these state law claims created no conflict with federal law, they were not impliedly preempted. ${ }^{233}$

225. Id. at *1.

226. Id.

227. Id.

228. Id.

229. $I d$. at $* 2$

230. 531 U.S. 341 (2001).

231. Ossim, $2014 \mathrm{WL} 4908574$, at *3.

232. $I d$.

233. Id. 